\title{
APPROACHES TO DETERMINING THE STAGES OF THE LANGUAGE TEACHING METHODS DEVELOPMENT IN WESTERN UKRAINE (1867-1939)
}

\author{
Bogdana Labinska \\ Yuriy Fedkovych Chernivtsi National University, Chernivtsi, Ukraine \\ b.labinska@chnu.ud.ua
}

\begin{abstract}
The article under discussion focuses on scientific works, dedicated to the development of language teaching methods. We have analysed the criteria for singling out the stages of contemporary scholars' methods of development and created our own criteria regarding language teaching methods in Western Ukraine (1867-1939). According to the selected criteria, we have determined the basic stages of development methods on a particular territory, in a specific chronological framework: stage I - 1867-1890 - the emergence of the language teaching methods; stage II - 1890-1918 - the formation of foreign language teaching methods; stage III 1918-1939 - further development of language teaching methods. These stages have been marked with certain innovative ideas of foreign language teaching approaches. They have also set certain scientific practice standards and theoretical postulates, preserving, at the same time, the teaching theories, concepts, approaches, principles, foreign language teaching methods, accepted by the professional community. Certain approaches to curricula development, in accordance with the peculiarities of each region, some principles of creating the educational materials, regarding the students' age and interests, are inherent to each phase of the development of Linguistic Didactics in Western Ukraine. In our studies, we have proved that grammar translation, textual translation, direct and mixed methods of foreign language teaching have been implemented in accordance with the characteristic features of the outlined area and within the fixed chronological frames. We have highlighted the provisions of foreign language teaching methods that have remained unchangeable in the process of foreign language teaching in Western Ukraine. The latter methods have acquired new features and emerged in foreign language teaching methods on Western Ukrainian territories during their implementation within a specified period of time.
\end{abstract}

Keywords: language teaching methods; Western Ukraine; stages; criteria; periods.

\section{Introduction}

The nation's past is closely bound to its present and its future. It is impossible to build the future without being aware of the past. Recommendations, pieces of advice, scholarly discoveries of creative teachers and educational leaders, many ideas that appear in the scientific works of forgotten and halfforgotten linguistic pedagogues, are still relevant today (Yavorska, 2004, p. 4). What has already been said, concerns foreign language teaching methods (FLTM) in Western Ukraine (the second half of the XIX - the first half of the XX century). It perfectly fits the globalisation theory as an extension and retrospective knowledge deepening on the background of parallel processes of differentiation, regionalization and multiculturalism. The research of the FLTM development stages in the Western Ukrainian area enables to trace clearly approaches, principles and methods of foreign language teaching (FLT) dynamics. The chronological scope of the studies fully and dynamically takes into account historical, political and social factors that have affected the development of FLTM.

It should be emphasised that the territorial boundaries in the FLTM development research embrace the areas of Western Ukraine: Galicia, Bukovyna, Transcarpathia, and Western Volyn. All these lands used to belong to other countries. At the period of 1867, Galicia, Bukovyna and Transcarpathia were a part of Austro-Hungary, whereas since 1918 Galicia and Western Volyn belonged to Poland, Bukovyna - to Romania, Transcarpathia - to the Czech Republic.

The analysed research sources that cover the FLTM history-related issues, in particular, the works by Rakhmanov (1947), who studied the methodological problems of new nineteenth and twentieth centuries Western European languages learning); Rauschenbach (1971) analysed the methods from the I till the XX century); Vedel (1979) continued researching this issue up to the mid-twentieth century); Mirolyubova (1973) reviewed the status of FLTM in XX-XXI centuries); Kuznetsova (1969) studied the history of FLTM in the Soviet non-lingual universities); Nikonova (1969) analysed the FLTM development from 1900 to 1923); Rieger (1970) investigated the history of the teaching methods of German in Galicia from the end of XVI century up to 1918); Kapitonova, Moskovkin \& Shchukina (1979; 1987; 2008) analysed methods of teaching Russian as a foreign language); Gez \&Frolova (2008) studied the history of continental FLTM; and others, enable to claim that the FLTM development on the lands of the Western region has not been the object of a thorough scientific research.

Taking into account the above-mentioned information, the objective of the article under discussion is to analyse the criteria for determining the stages of foreign language teaching methods in Western Ukraine (in the second half of the XIX - the first half of the XX century.). 


\section{Methods}

The following research methods have been implied for fulfilling the necessary tasks at different stages of scientific search: the FLT methods, that existed on the territory of Western Ukraine during the period under the study, have been investigated by means of critical analysis of Ukrainian and foreign psychological, linguistic and methodological literary sources, educational documents, curricula and FL textbooks; the monitoring and summarizing the FL teachers' positive experience have been performed through analysing the methods, approaches, didactic and methodological principles, techniques, and methodological solutions, the application of which increased the efficiency of the teaching process; the course of certain historic events in a proper chronological order has been arranged within the narrative method; the hermeneutic method has been applied with the purpose of word-to-word preservation of the authentic contents, since it was to be translated and interpreted in the very same way, it had been comprehended by the authors of that time (using the relevant notions and categories of that period, as well as preserving the authentic titles of textbooks, articles, and other literary sources; certain terms, peculiar for the present-day stage in the FLTM development, have been used in summarizing the article results; the historical-structural method has stipulated the structure of the accumulated historical-methodological information, as well as has enabled to correlate it with certain historic periods; the historical-genetic method has been directed to investigating the initial stage (the occurrence of FLTM on the territory of Western Ukraine), which allows to distinguish on its basis some further stages (the FLTM consequent development in Western Ukraine). This method has also served for working out the FLTM development periodization; the historical-comparative method has become the basis for tracing up the FLTM development in European countries, in the Russian Empire, in the USSR, as well as for determining the specific features of the FLTM evolution in Western Ukrainian area during the period under the study; the historical-systematic method of studying the process of the FLTM development in various types of comprehensive schools in Western Ukraine has enabled a detailed description of the FLT system components on the western Ukrainian lands in 1867-1939 in historical retrospection.

\section{Results}

The description of the FLTM development in Western Ukraine includes the reasoning of its periodization, the latter reflecting some significant FLTM development features at different historical stages. Each stage contains certain historical, social, and educational pre-conditions of the FLTM development in Galicia, Bukovyna, Transcarpathia, and Western Volyn. It is important that according to the discovered sources (131 curricula, 61 textbooks, numerous narrative sources in different parts of Western Ukraine), Latin, Greek, English, German and French belonged to the foreign languages. This research lays particular emphasis on teaching English, German and French. As a matter of fact, the conceptual ideas of European scholars have had a considerable impact on the FLTM development in the western area. The works of these scientists were discussed on the pages of educational periodicals, whereas the results of their application were disputed at teaching conferences. The changes in the methodology of FLT included, mostly, the alteration in approaches, principles, methods and techniques. The FLTM development on Western Ukrainian territories in 1867-1939 acquires certain specific features of its own, being quite different from the similar processes taking place in the bordering countries. It particularly concerns determining the basic criteria of distinguishing the stages of its development; the chronological boundaries of the periods; the FLT methods, officially used in regulatory-legal documents.

\section{Discussion}

According to Suchomlynska (2003), one of the most important scientific problems, especially in arts, is the problem of periodization of any phenomenon, i.e. the determining of certain periods (p. 47). Retrospective and systematic conceptual analysis of the trends of FLTM development within the fixed chronological and territorial limits allowed periodizing in the context of historical, social, economic, socialpolitical and methodological determinants.

The highlighting of the FLTM development stages in Western Ukrainian lands enabled to find out the main directions, trends and contradictions in the formation of a certain system. This very system is considered to be an important condition in terms of following the development and dialectics of the traditional and the innovative in the latest models because of its unity, continuity and progressivity of the historical process. These methodological concepts that are studied in a historical perspective, enable to plunge deeper into the extra-linguistic context where they derive and develop.

Having analysed the works, dedicated to the problem of the FLTM periodization by such Russian scientists as Bakhtiarova \& Schukin (1988), Mirolyubov (1973), Moskovkin (2008), Misechko (2011), in which they have justified the criteria and marked the FLTM development stages, we would like to focus 
attention on the fact that the authors have covered chronological and territorial boundaries (the period up to 1939), beyond the western territories.

The first attempt to scientifically substantiate the periods, reflecting the patterns of FLTM at different historical stages objectively, as well as to determine the criteria for singling out certain periods, was made by a Russian methodologist Mirolyubov (1973). The scientist suggested and described the following periodization criteria: 1) fundamental changes in the FLT objectives; 2) fundamental changes in the very methodical science which are associated with new teaching ideas and which required a radical revision of a number of problems. Furthermore, the author of the article points out that the impact of European teachers and their methodological works served as an impulse for conversing the FLTM development stages.

The suggested periodization criteria made it possible to determine the FLTM development stages in the Russian Empire and the Soviet Union, excluding the western lands, during the following chronological periods: 1860-1917, 1917-1930; 1930-1941; 1940-1950; 60-ies, 70-80-ies of the XX c.

To periodize the history of teaching methods of Russian as a foreign language Bakhtiarova and Schhukin (1988) distinguish between the following criteria: 1) social, economic and political factors that influence the development of methodologies; 2) qualitative changes in the methods of teaching due to the changes in the objectives, content, teaching methods and tools; 3 ) the advances in the related sciences. The authors suggest the following periods: 1917-1945, 1945-1959, 1960-1969, 1970-1979 and 1980. Thus, in addition to qualitative changes in the methods of teaching Russian as a foreign language, the transition from one stage to another is characterised by such external factors as social, economic and political as well as the progress in the related sciences.

When reviewing the main directions of teaching ideas in Russia, Moskovkin (2008) offers the following stages: XVIII c.- 90 -ies of the XIX c.; 90-ies of the XIX c. - beginning of the XX c.; 30-50-ies of the XX c.; 60-80-ies of the XX c.; from 1991 to 2008 . He believes that the main factor of the interchange between the stages is the emergence of basic methodological innovations, accompanied by the following supporting factors: social, economic and political progress in the related sciences, change of the learning objectives. Besides, the impact of foreign methods is the additional factor since it partially facilitates the change from one stage to another.

A contemporary Russian methodologist Galskova (2011) shares this opinion. She emphasises that when considering the history of a certain methodological model, we do not analyse social, political and economic backgrounds of a new development direction, but conduct a search of its origins in the depths of the basic sciences, primarily in linguistics and psychology. The main object of the study within the methodology is language (and today it is lingual culture) as a social phenomenon and the experience of mastering it, which has a clear psychological and social-cultural foundation (Galskova, 2011, p. 3). The author considers the development of the methodology-related sciences to be the main precondition of the change from one concept into another.

In his historical and pedagogical research of professional training of the FL teachers of Ukrainian educational institutions (early 1900-ies - early 1960-ies.), a contemporary teacher Misechko (2011) identifies the following criteria: objective change of social role and the FL value and its legal framework security; the quantitative institutional changes (in the social area and time) in the network of foreign language vocational teaching education; the semantic and organizational improvement, the improvement of the level of integrity of professional training; capacity building of the FL teachers training system. The author also relies on the periodization parameters of the FL teachers' vocational training - social-cultural actualization of foreign language education; the level of social need in the FL teachers; structural harmonisation of the professional training; the perspective of the training development. Concurrently, Misechko (2011) studies the FL teachers' training in Ukrainian educational institutions, when in 1917-1930 their own system of school and professional education was created, and in the 1930-ies the unique network of professional foreign language education institutions was developed (pp. 36-37). The scientist highlights the main stages of the formation of the system of the FL teachers' professional training: 1900-1917 phase I; 1917-1930 - phase II; 1930-1940 - phase III; 1941-1964 - phase IV.

Therefore, considering the FLTM development periods as an important basis of our work, it should be noted that they do not take into account the regional peculiarities of schooling in other republics. They are focused only on the FL teachers' training in educational establishments of Ukraine. Most approaches are similar and related to the history of Russia, the Union of Soviet Socialist Republics, Ukrainian Soviet Socialist Republic, i.e. to the Russian and Soviet education systems. The only difference lies in the stages and criteria that the authors have considered as most significant for the FLTM development.

Thus, summarizing the results of the historical and methodological search and considering them as the basic periods of this investigation, we may determine the main criteria of the FLTM development in Western 
Ukraine (1867-1939): 1) the historical, social and political factors that influenced the FLTM development; 2) the impact of the foreign FLTM; 3) the changes in the very methodological science that are associated with new teaching ideas, objectives, content, methods and teaching aids.

According to these criteria, the basic FLTM development stages in Western Ukraine have been defined as follows: stage I - 1867-1890; stage II - 1890-1918; stage III - 1918-1939.

The first stage (1867-1890.) is marked with: the affiliation of Western Ukraine to Austria-Hungary; the adoption of the Austrian constitutional laws, including the law for the right to study in the mother tongue; the separation of school from the church; obligatory attendance of primary school; the introduction of private schools.

The development of Western Ukrainian territories was not at all a detached and segregated process. The western Ukrainian FL teachers applied in their work various progressive ideas of the leading European methodologists. The innovations were implemented neither mechanically, nor automatically. They were adjusted to the areal peculiarities, as well as to the needs and interests of the Ukrainian community. The information, concerning the FLTM development in other countries, has been obtained from different educational periodicals, that contained some fundamental investigations of European scientists of that time and were available in most libraries.

In the course of analysing the research sources in various parts of Western Ukraine, we have managed to ascertain that Ukrainian teachers were familiar with the fundamental works and new teaching concepts of the European scholars of those times: M. Berlitz, I. Meidenherr, G. Oleandorf, V. Vietor, and others.

Besides, the pages of certain educational periodicals of that time ("Uchytel", "Nasha Shkola", "Uchytelske slovo", "Uchytelskyj holos", Kalendar "Oswita", "Shkilnyj calendar na zwychajnyj shkilnyj rik", "Shljach vychovanja i navchanja", "Ukrajinska shkola", "Muzeum" (Galicia); "Kamenjari”, "Shkolnaja chasopys", "Bukowiner Schule", "Bukowiner pädagogische Blätter", "Bukowiner Schul-Zeitung" (Bukovina); "Podkarpatsksja Rus", "Uchytel", "Nasha Shkola" (Transcarpathia); "Rilnyk", "Do prazi" (Western Volyn) have been assigned for discussing advantages and drawbacks of applying different methods in FL teaching, that had been worked out and introduced by the European scientists.

At this time, the FL (English, German, French) teaching methodology was also marked with laying some scientific foundation for its functioning, as well as forming the curricula on the basis of FL textbooks in students' native language. Another important peculiarity was the growing popularity of works that revealed methodological problems, which, in its turn, has stipulated the formation of scientific foundations and the occurrence of the FL teaching methods.

After Kolkova (2008, p. 31), who divides the main curricula categories into synthetic and analytical, the first phase curricula should be classified as synthetic applications, in which the emphasis was laid upon the certain elements of the language system.

To analyse the FL curricula, that were worked out in Western Ukraine (1867-1939), the following criteria were outlined: compliance with the social order of the society; approval of the relevant state educational authority; the specificity of the definition of the objectives, the content and the periodization frames of the FLT; the availability of the methodological guidelines for the organisation of the FLT process; the compliance with the school type requirements, depending on its orientation; curriculum availability; availability of the language and speech material for each year of study; recommendations on the use of means of current and final control of educational achievements of the FL students; availability of the FL textbooks for different types of schools, authorized by the proper educational bodies.

Publishing FL textbooks in Ukrainian was a significant step forward in the FLTM development. In different parts of Western Ukraine of 1867-1890, the FL textbooks are divided into three groups.

The content and structure of the textbooks were based on such didactic principles as grading the educational material from simple to complex, taking into account the age characteristics of language learners and others.

The analysis of the FL textbooks in Western Ukraine has been made on the basis of the Borysko's hierarchical scheme of structural and content analyses of teaching and methodological complexes (Borysko, 1999, pp. 22-25).

The FL teaching in 1867-1890-ies was based on conceptual and methodological fundamentals of such FL methods as grammar translation and textual translation. The didactic principles include: the principle of educative learning, capability, strength, conscious learning. At that time the leading methodological principle was the principle of the native language consideration.

The implementation of the translation methods of FLT in Western Ukraine rested on three provisions that were laid by their founders and have not changed in FL teaching in Western Ukraine: 
- the FL teaching was based on writing samples;

- in the process of FL teaching the translation from any FL into the native language was used for the semantisation of words and when performing certain exercises;

- when using grammar translation method, deduction and synthesis were considered as the major processes of logical thinking (the FL teaching started with learning of the grammar rules and lexical items by heart, since the sentence was based on them), the analysis of cohesive original texts when using textual translation method (the FL teaching started with reading the original writing samples, on the basis of which grammar was taught).

The four provisions that have promoted other features of FL teaching in Western Ukraine:

- teaching foreign language grammar was performed by comparing certain grammatical structures of FL to native language (in the use of grammar translation method), not to Latin, as done by its founders;

- teaching grammar involved the students' understanding of language phenomena, language characteristics, and not by mechanical learning;

- selection of the lexical units covered not only grammar terminology, but also the texts for reading;

- not literal translation, but the rendering of the contents of a sentence was recommended in the process of FL teaching.

The four new provisions, that emerged in the FL teaching methods in the process of the implementation of translation methods in Western Ukraine, have promoted the following:

- when teaching reading, the difference between letter and sound was explained;

- teaching reading and writing was an inseparable unity, whereas reading was considered as a form of preparation for learning to write;

- in the process of teaching to read, German students were getting acquainted with the history and geography not only of Austria-Hungary, but also of their Motherland and other European countries. Such an approach laid the foundation of knowledge of culture, history, traditions and realities of the country, the language of which was studied;

- the FL teaching was carried out with the consideration of students' personal abilities to master FL using tasks differentiation in accordance with their complexity.

The second stage (1890-1918) is marked by the educational reforms, which led to the expansion of knowledge in arts, whereas the FL teaching, in particular, was seen as an important means of deepening this knowledge. On the pages of various periodicals appeared the works with critical analysis of the FL teaching practice. This led to the substitution of descriptive and explanatory methods by the empirical-descriptive one. The publication of the first theoretical papers and the use of theory in FL teaching have caused the formation of FLTM in Western Ukraine.

The FL curricula of the second stage were of contextual and situational types. The basis of thematic programs were the topics that students had to learn during the training with consideration of lexical and grammatical material that was subject to activation. In addition, a certain sequence of real and fictional speech situations was included into the content of the FL curricula.

The analysis of the selected FL textbooks draws us to the conclusion that during 1890-1918 there took place a transition from the translation method to the direct method.

We have divided FL textbooks under research into three groups.

The FL teaching in western Ukrainian lands was carried out on conceptual and methodological ideas of the direct method and was based on speech and cultural approach. The didactic principles, popular during this period, have been supplemented by the principles of visual aids, consistency and regularity. The principle of oral advance was also added to other teaching principles.

The implementation of the direct teaching method of FL teaching was based on three provisions that have not changed in FL teaching in Western Ukraine:

- FL teaching meant acquiring spoken language based on live, everyday language;

- FL teaching was conducted in accordance with phonetic rules;

- for lexical material teaching visual (pictures, objects, models, activity simulation) and verbal aids (synonyms, antonyms, word formation, definitions, etymology, context etc.) were used.

The three provisions, that have acquired different features in the process of FL teaching in Western Ukraine:

- in primary school, the native language was used to explain unfamiliar vocabulary and grammatical phenomena;

- at the initial stage teaching grammar was carried out by means of the rules;

- at the advanced level of FL teaching, the translation was used to control lexical and grammatical 
knowledge.

The three new provisions that emerged in FLTM in Western Ukraine during the implementation of the direct method:

- when teaching foreign language reading, some information on the XVIII-XIX c. history and literature was required;

- in the process of reading the students were introduced to all genres of fiction;

- FL teaching provided a comparison of FL linguistic phenomena with native language linguistic phenomena.

The third stage (1918-1939) is characterised by joining of Eastern Galicia and Western Volyn to Poland, Bukovina - to Romania, Transcarpathia - to Czechoslovakia. On September 28, 1939, the SovietGerman Treaty on Friendship and Borders was signed. In compliance with it, Galicia and Western Volyn became an administrative part of the Ukrainian Soviet Socialist Republic. In this respect, it would be expedient to determine the year 1938 as the top periodization point of the stage under discussion. The education reform was conducted throughout Western Ukraine. The further development of FLTM was happening as a purposeful, specially organised process. Cognitive-creative search clarified and justified certain theoretical concepts (in particular, the terms "individualization of learning", "dramatisation", "active and passive lexical units", "orientation reading" were introduced), thus deepening students' knowledge about the culture of the people, whose language was studied, etc.

FL curricula in Western Ukraine during the above mentioned period apply to structural, thematic and situational types. The combination and integration of different types of curricula have contributed to the specific and detailed description of the process of FL teaching.

The works of Transcarpathian and Volynian teachers state the fact of usage of curriculum and textbooks of Galician teachers in all subjects.

We split FL textbooks in Western Ukraine into two groups.

The content and structure of FL textbooks in Western Ukraine met the requirements of the curriculum, which was approved by the Ministry of Education of the country, to which one or another territory of Western Ukraine belonged.

FL teaching was based on conceptual and methodological ideas of the mixed method and on language, speech, cultural, cognitive, integrated approaches. To the didactic principles of the previous chronological periods was added the principle of individualization. Methodical principles have been supplemented by the principles of situational-thematic organisation of educational material and stylistic differentiation.

The implementation of the mixed method of FLT in Western Ukraine took place with the consideration of the three provisions that did not change in Western Ukraine during the studied period:

- teaching of different aspects of language was interrelated and subordinate to the teaching of speaking;

- teaching vocabulary and grammar was conducted by its explanation in students' native language;

- FL teaching was conducted as a combination of realisation and intuition.

The two provisions, that acquired other features in FL teaching in Western Ukraine, have also facilitated the following:

- teaching grammar presupposed learning grammar rules;

- teaching translation was based on the requirements of contemporary FL curriculum for each Western Ukrainian territory.

On three new provisions that emerged in the FLTM in the mixed method in Western Ukraine:

- FL teaching was conducted on the basis of personal abilities of students to master a foreign language;

- teaching foreign language communication was thematically and situationally conditioned (the majority of the mixed method supporters did not take into account the importance of the situational and thematic organisation of the educational process);

- teaching speaking was conducted with the use of dramatisation.

\section{Conclusions}

Thus, the introduction of the basic periodization criteria of the FLTM development in Western Ukraine (second half of the XIX - first half of the XX centuries) made it possible to distinguish the following stages of FLTM: 1867-1890 - the first stage, 1890-1918 - the second stage, 1918-1939 - the third stage. These stages are marked with innovative ideas about the nature of the FLT methods, and the establishment of certain standards of scientific practice and theoretical postulates, preserving the generally accepted things in 
the professional community teaching theories, concepts, approaches, principles, FLT methods. This vector of scientific research in FLTM aims at the development and improvement of the students' personal abilities in the process of FL mastering, learning the culture and the society of other linguistic ethnical groups.

The further prospects of investigation might cover the studies of the development of the German Language teaching methods at various types of Bukovynian schools.

\section{References:}

Bachtijarova, Sh. (1988). Istoryya metodyky prepodavaniya russkogo yazyka kak inostrannogo [The History of the methods of teaching Russian as a foreign language]. Kyiv, Ukraina: Vyshha skola.

Borysko, N. (1999). The criteria of the analysis and evaluation of textbooks and teaching-methodological complexes in foreign languages. Inozemni movy, 1, p. 22-25.

Vedel, H. (1979). Iz istoriy metodov prepodavaniya inostrannych yazykov [From the history of foreign languages teaching methods]. Voronezh, Russsia: Voronezhskyy universytet

Galskova ,N. (2011). Osnovnyje paradigmalnyje cherty sovremennoj metodicheskoi nauki. [The main paradigmatic features of the contemporary methodological science]. Innostrannye yazyky $v$ shkole, 7, p. 3-11.

Gez, N. \& Frolova, H. (2008). Istoriya zarubezhnoj metodyky prepodavanya inostrannych yazykov [The History of the foreign methods of foreign languages teaching]. Moscow, Russia: Akademija.

Kolkova, M. (2008). Metodyka obucheniya inostrannym yazykam v srednej shkole [The Methods of foreign language teaching in secondary school]. Moscow, Russia: KARO.

Myroljubov, A. (1973). Istoriya metodyky obuchenya inostrannym jazykam v SSSR [The history of forein languages teaching methods in the USSR]. Extended abstract of candidate's thesis, Moscow, Russia.

Misechko, O. Ye. (2011). Formuvannya systemy profesijnoyi pidgotovky vchytelya inozemnoyi movy u pedagogichnyx navchalnych zakladach Ukrainy (1900-1964 pp.) [The Development of foreign languages teacher's training system in pedagogical teaching institutions of Ukraine (1900-1964)]. Zhytomyr, Ukraine.

Suchomlynska, O. (2003). Istoryko-pedagogichny proces: novi pidchody do zagalnych problem [The historical pedagogical process: new approaches to common problems]. Kyiv, Ukraine: A.P.N.

Rauschenbach, V. (1971). Kratkyj obzor osnovnych metodov prepodavanyya inostrannych yazykov s I po XX vek [The Schort review of the main methods of foreign languages teaching from 1 till XX c.]. Moscow, Russia: Vyshha skola.

Raxmanov, Y. (1947). Ocherk po istoryy metodyky prepodavanyya novyx zapadnoevropejskyx inostrannych yazykov [The layout of the new Western European foreign languages teaching methods]. Moscow, Russia: Uchpedgiz.

Riger, M. (1970). K istoriy razvytyya metodyky obuchenyya zhyvym inostrannym yazykam na zapadnoukraynskych zemlyach (s konza XVI veka po 1918 god) [To the history of the development of live foreign languages teaching methods in Western Ukraine (from the end of XVI c. till 1918)]. Extended abstract of candidate's thesis, Minsk, Belorusia.

Yavorska, S. (2004). Stanovlennya i rozvytok metodyky navchannya ukrayinskoyi movy v pochatkovych klasach (30-90 roky XX st.) [The establishment and development of Ukrainian language teaching methods in primary school (30-90 of the XX c.)]. Slavyansk, Ukraine: PP "Kanzler". 